\title{
Terapi Murotal Al-Qur'an Surat Arrahman Meningkatkan Kadar 6-Endorphin dan Menurunkan Intensitas Nyeri pada Ibu Bersalin Kala I Fase Aktif
}

\section{Al Qur'an Surah Arrahman Recital Therapy Increase 6-Endorphin Levels and Reduce Childbirth Pain Intensity on Active Phase in First Stage}

\author{
Wahida $S^{1}$, M Nooryanto $^{2}$, Sri Andarini ${ }^{3}$ \\ ${ }^{1}$ Program Studi Magister Kebidanan Fakultas Kedokteran Universitas Brawijaya Malang \\ ${ }^{2}$ Divisi Feto Maternal Obstetri Ginekologi Fakultas Kedokteran Universitas Brawijaya Malang \\ ${ }^{3}$ Fakultas Kedokteran Universitan Brawijaya Malang
}

\begin{abstract}
ABSTRAK
Persalinan adalah proses alami dan menimbulkan nyeri, namun banyak ibu yang tidak bisa menahan rasa nyeri tersebut karena dipengaruhi oleh stres. Terapi non farmakologi yang dapat digunakan untuk mengurangi rasa nyeri adalah Murotal Al-Qur'an. Terapi ini dapat menstimulasi gelombang delta yang menyebabkan pendengar dalam keadaan tenang, tentram dan nyaman sehingga hypopfise dan hypothalamus mengeluarkan B-Endorphin sebagai analgesik alamiah. Tujuan penelitian ini membuktikan bahwa terapi murotal Al-Qur'an Surat Ar-rahman dapat meningkatkan kadar B-Endorphin dan menurunkan intensitas nyeri persalinan pada kala I fase aktif. Penelitian ini dilakukan di rumah sakit Abunawas Kendari dan Laboratorium Fakultas Kedokteran UNHAS. Desain penelitian Quasi-Experimental dengan pendekatan PreExperimental design One-Group Pre-test-Post-test. Pengambilan sampeldengan tehnik purposive sampling sebanyak 30 orang. Pengukuran kadar B-Endorphin dilakukan dengan ELISA kit dan intensitas nyeri persalinan diukur dengan menggunakan Bourbannis pain scale. Analisis data dengan Kolmogorov-Smirnov dan uji $t$ berpasangan. Hasil penelitian menunjukkan ada penurunan signifikan intensitas nyeri sebelum $(6,80 \pm 1,52)$ dibandingkan sesudah $(3,37 \pm 1,79)$ pemberian terapi murotal Al-Qur,an surat Ar-rahman selama 25 menit $(p=0,000)$. Terapi murotal Al-Qur'an juga menunjukkan peningkatan signifikan $(p=0,000)$ kadar B-Endorphin sebelum perlakuan $(1053,6 \pm 606,32 \mathrm{ng} / \mathrm{L})$ dan setelah perlakuan $(1813,6 \pm 546,78 \mathrm{ng} / \mathrm{L})$. Dapat disimpulkan bahwa pemberian terapi murotal Al-Qur'an dapat menurunkan intensitas nyeri dan meningkatkan kadar B-Endorphin.
\end{abstract}

Kata Kunci: B-Endorphin, intensitas nyeri, kala I fase aktif, murotal surat Arrahman

\begin{abstract}
Childbirth is a natural process and causes pain however many mothers affected by stress couldn't with stand the pain. Al Qur'an recital as a non-pharmacological therapy can be used to reduce pain. This therapy stimulates delta waves which make the listener more relax, peaceful, and comfortable so that hypopfise and hypothalamus produce b-endorphin as natural analgesic. This research aims to prove that Al Qur'an surah Arrahman recital therapy may increase B-endorphin level and reduce child birth pain intensity on active phase in first stage. The research was conducted at Abunawas Kendari regional hospital and medical faculty laboratory of UNHAS. The research used Quasi-Experimental with Pre-Experimental design One-Group Pre-test-Post-testapproach. The samples were 30 mothers by using purposive sampling methods. BEndorphinwas measured by using ELISA kit and childbirth pain intensity was measured by using Bourbannis pain scale. Data were analyzed with Kolmogorov-Smirnov and paired t test. The result shows there was a significant decrease in pain intensity before $(6,80 \pm 1,52)$ than after $(3,37 \pm 1,79)$ the recital therapy for 25 minutes $(p=0,000)$. Qur'an recital therapy also showed a significant increase $(p=0,000)$ on B-Endorphin levels before treatment $(1053,6 \pm 606,32 \mathrm{ng} / \mathrm{L})$ and after treatment $(1813,6 \pm 546,78 \mathrm{ng} / \mathrm{L})$. It can be concluded that Qur'an recital therapy can reduce pain intensity and increase levels of 6-Endorphin.
\end{abstract}

Keywords: 6-Endorphin, childbirth pain intensity, active phase in first stage, surah Arrahman recital

Jurnal Kedokteran Brawijaya, Vol. 28, No. 3, Februari 2015; Korespondensi: Wahida S. Program Studi Magister Kebidanan Fakultas Kedokteran Universitas Brawijaya Malang, Jl. Veteran Malang Tel. (0341)569117Email: wahida.azis@yahoo.co.id 


\section{PENDAHULUAN}

Persalinan merupakan suatu proses alami dan menimbulkan rasa nyeri. Banyak wanita yang tidak bisa mentolelir rasa nyeri tersebut karena banyak dipengaruhi oleh stres yang disebut fear, tension, pain (takut, tegang, nyeri). Hal tersebut menimbulkan ketegangan atau kepanikan yang menyebakan rasa sakit (1). Dengan meningkatnya perasaan nyeri, ibu selalu meminta agar persalinannya di percepat dan ingin diberikan obat penghilang rasa nyeri dan sebagian lagi ingin dilakukan operasi (2). Nyeri merupakan suatu kondisi yang paling tidak disukai dan bahkan ditakuti terutama oleh ibu hamil dan ibu yang hendak bersalin (3). Rasa takut dalam persalinan menjadi alasan utama bagi ibu hamil untuk memilih persalinan dengan bedah sesar yang dilakukan tanpa indikasi medis, melainkan permintaan ibu hamil yang memandang bedah sesar merupakan alternatif yang lebih baik dibanding dengan persalinan normal (4).

6-Endorphin adalah neuropeptide yang terdiri dari 31 asam amino yang diproduksi oleh kelenjar hypofise merupakan hasil pembelahan dari Proopio Melano Cortin (POMC) (5). POMC adalah protein yang besar yang membelah menjadi protein yang kecil seperti BEndorphin. Dalam sistem saraf perifer B-Endorphin menghasilkan analgesik dengan mengikat receptor opioid terutama di tipe $\mu$. Ikatan tersebut menyebabkan interaksi penghambatan pelepasan tachykinins khususnya substance peptide, protein kunci yang terlibat dalam transmisi nyeri. Dalam sistem saraf perifer opioid- $\mu$ terdapat disepanjang saraf perifer dan sistem saraf pusat (SSP), B-Endorphin juga mengikat receptor opioid- $\mu$ sehingga terjadi interaksi diterminal saraf presinaptic dan juga menghambat substance peptide, menghasilkan efek analgesik dengan menghambat pelepasan Gamma Butyric Acid (GABA), inhibitory neurotransmitter. Dalam Sistem Saraf Pusat (SSP) receptor opioid yang paling banyak dihasilkan dijalur decenden neorotransmitter dalam mengontrol nyeri, termasuk amygdala, formasireticular mencephalic, materi abu abu periaqueductal (PAG) dan rostal medulla (6). 6-Endorphin merupakan neuropeptide. Terdapat 3 macam neuropeptide yaitu endorphin alfa, beta dan gamma yang semuanya dapat berikatan dengan receptor opioid dalam otak dan aktifitasnya sangat kuat, endorphin beta terdapat dalam adenohypofise, hypothalamus yang fungsinya untuk mengurangi rasa nyeri (7).

Terapi murotal Al-Qur'an atau bacaan AL-Qur'an dengan keteraturan irama dan bacaan yang benar juga merupakan sebuah musik Al-Qur'an mampu mendatangkan ketenangan dan meminimalkan kecemasan $97 \%$ bagi mereka yang mendengarnya $65 \%$ mendapatkan ketengan dari bacaan Al-Qur'an dan 35\% mendapatkan ketenangan dari bacaan dalam bahasa Arab bukan Al-Qur'an (8). Dari hasi penelitian yang dilakukan di RSUD Ambarawa Kabupaten Semarang sekitar $41,7 \%$ ibu bersalin mengalami nyeri berat dan $58,3 \%$ mengalami nyeri sangat berat. Penelitian yang dilakukan di Bidan Praktek Swasta (BPS) di Surabaya didapatkan hasil 82,21\% ibu bersalin pada fase aktif yang mengalami nyeri berat (9).

Terapi non farmakologi yang dapat digunakan mengurangi rasa nyeri salah satunya dengan menggunakan teknik distraksi dengan ayat suci Al-Qur'an yang dapat menstimulasi gelombang delta yang menyebabkan pendengar dalam keadaan tenang, tentram nyaman (10). Relaksasi religius yang dikembangkan Benson menggabungkan relaksasi dengan faktor keyakinan dapat menciptakan kekuatan dari dalam yang membantu seseorang dalam keadaan rileks. Dengan menganalogikan bahwa bacaan Al-Qur'an juga mempunyai tempo lambat, teratur dan lembut serta faktor keyakinan diharapkan dengan mendengar bacaan AL-Qur'an dapat menimbulkan relaksasi (11).

\section{METODE}

Penelitian ini menggunakan Quasi Ekperiment dengan pendekatan Pre-Experimental design One-Group Pre-testPost-test. Penellitian ini melibatkan responden sebanyak 30 orang ibu bersalin kala I fase aktif. Dilakukan pengukuran sebelum dan sesudah perlakuan yaitu pengukuran intensitas nyeri dan pengambilan sampel darah. Pemeriksaan kadar 6-Endorphin di lakukan di laboratorium pusat penelitian Fakultas Kedokteran Rumah sakit Universitas Hasanuddin Makassar. Pengukuran intensitas nyeri menggunakan skala nyeri Bourbannis yang dilakukan di kamar bersalin untuk menilai nyeri persalinan pada ibu Kala I fase aktif.

Ibu bersalin yang menjadi subjek penelitian ditentukan berdasarkan kriteria inklusi ibu dalam kala I fase aktif, bersedia menjadi responden dan beragama Islam. Peneliti menetapkan kriteria eksklusi sebagai berikut: ibu hamil gemeli, menderita penyakit (DM, hipertensi, jantung), ibu di diagnosa pre-eklamsia atau eklamsi, dan ibu mempunyai kelainan pendengaran. Ibu bersalin yang bersedia menjadi responden dijelaskan mengenai tujuan dan manfaat serta kemungkinan yang dapat terjadi selama penelitian berlangsung, kemudian meminta ibu untuk menandatangani pernyataan informed consent. Pemantauan kondisi ibu dilakukan menggunakan format partograf untuk menilai kemajuan persalinan, bila sudah masuk dalam kala I fase aktif yaitu pembukaan $4 \mathrm{~cm}$ dengan pemeriksaan yang dilakukan oleh bidan. Dilakukan pengukuran intensitas nyeri menggunakan format skala nyeri Bourbannis. Pengambilan sampel darah sebanyak 2 $\mathrm{ml}$ dilakukan sebelum terapi murotal Al-Qur'an surah Arrahman dan 5 menit segera setelah dilakukan pengukuran intensitas nyeri dan pengambilan sampel darah.

Bahan penelitian 6-Endorphin menggunakan plasma darah yang diambil dari darah perifer sebanyak $2 \mathrm{ml}$, sampel darah dimasukkan ke dalam tabung polypropylene yang berisi Ethylene Diaminetra Acetate (EDTA) sebagai antikoagulan. Pemeriksaan kadar B-Endorphin menggunakan Human B-Endorphin Enzim Linked Immuno Sorbent Assay (ELISA) kit. Cat No. E 12991 HU. Dalam pemeriksaan laboratorium kadar B-Endorphin digunakan: Human B-Endorphin ELISA kit, Shaker ELISA plate, Multi Chanel plate, Micropipet, Micro centrifuge tube $5 \mathrm{ml}$, Blue tip, yellow tip, white tip, ELISA Reader $450 \mathrm{~nm}$, Ethylene Base Steriamid (EBS), Phosphate Buffered Saline (PBS) Tween, Vortex, Inkubator. Bahan dan Reagen yang disediakan dalam kit: Standar (1600 ng/L), Standard diulent $3 \mathrm{ml}$, Microelisa Stripplate $12 \times 8$, StreptavidinHorseradish Peroxidase (Str-HRP) Conyugate Reagent $6 \mathrm{ml}$, 30x wash solution $20 \mathrm{ml}$, Biotin B -Beta Endorphin Anty body $1 \mathrm{ml}$, Chromogen Solution $A, 6 \mathrm{ml}$, Chromogen Solution B $6 \mathrm{ml}$, Stop Solution $6 \mathrm{ml}$, intruction $1 \mathrm{ml}$, Closure 
Plate Membrane 2, Saled Bags 1.

Sampel darah perifer sebanyak $2 \mathrm{ml}$, dimasukkan ke dalam vacutainer yang berisi EDTA selanjutnya di sentrifugasi selama 20 menit dengan kecepatan 3000rpm, dibuat standar sesuai dengan instruksi di tabel 1600,800ng/L, 400ng/L, 200ng/L,100ng/L, 50ng/L. Sampel dimasukkan ke dalam well kosong sebanyak $40 \mu \mathrm{L}$, ditambahkan antibodi sebanyak $10 \mu \mathrm{L}$ pada masing masing well, ditambahkan streptavidin HRP 50 $\mu$ L pada masing masing standar. Selanjutnya pada masing masing well di vortex, diinkubasi selama 60 menit pada suhu $37^{\circ} \mathrm{C}$. Was solution diencerkan menjadi 300 menggunakan aquades, selanjutnya dicuci sebanyak 5 kali dan expirasi air yang tersisa sampai kering. Selanjutnya ditambahkan larutan chomogen A $50 \mu \mathrm{L}$, pada standar dan sampel, selanjutnya chromogen solution B $50 \mu \mathrm{L}$, untuk setiap well, dan di inkubasi selama 10 menit pada suhu $37^{\circ} \mathrm{C}$. Proses selanjutnya ditambahkan stop solution $50 \mu \mathrm{L}$ untuk merubah reaksi warna biru menjadi kuning, kemudian dimasukkan kedalam Elisa Reader dengan panjang gelombang $450 \mathrm{~nm}$. Pembacaan hasil dengan Opical Density (OD). Pembuktian hipotesis penelitian menggunakan Kolmogorov-Smirnov dan uji t berpasangan (paired sample $t$ test), dianalisis dengan bantuan piranti lunak SPSS (Statistical Producth And Servise Solution) for Windows.19.0.

\section{HASIL}

Pada penelitian ini sampel terdiri dari 1 kelompok, yaitu ibu bersalin kala I fase aktif, yang melahirkan di rumah sakit umum daerah Abunawas Kendari tahun 2014 dengan perlakuan terapi murotal Al-Qur'an surah Arrahman selama 25 menit menggunakan speaker box music dan earphone. Kelompok sampel ini terdiri dari 30 orang yang terpilih berdasarkan kriteria inklusi dan eksklusi. Tabel 1 menunjukkan sebaran data umur ibu

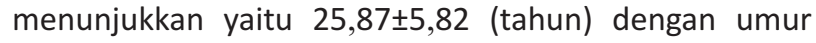
kehamilan mencapai yaitu 39,63 $\pm 0,77$ (minggu). Sebaran data berat bayi lahir menunjukkan yaitu $3173,33 \pm 311,76$ (gram). Sebagian besar ibu mempunyai tingkat pendidikan SMA (50\%), paritas ke $1(53,3 \%)$, dengan rerata usia kehamilan $39,63 \pm 0,77$ minggu. Semua sampel penelitian tersebut menunjukkan nilai apgar skor yang baik semua, yaitu dengan skor 7 sampai 9 dengan berat bayi lahir 3173,33 $\pm 311,76$ (gram).

Tabel 1. Karakteristik sampel penelitian

\begin{tabular}{|c|c|c|c|}
\hline Karakteristik sampel & rerata \pm stan.dev & $\mathbf{n}$ & $\%$ \\
\hline a. Umur ibu (tahun) & $25,87 \pm 5,82$ & 30 & 100 \\
\hline b. Umur kehamilan (minggu) & $39,63 \pm 0,77$ & 30 & 100 \\
\hline \multicolumn{4}{|l|}{ d. Tingkat pendidikan: } \\
\hline$-\quad S D$ & - & 2 & 6,7 \\
\hline - $\quad$ SMP & - & 7 & 23,3 \\
\hline - $\quad$ SMA & - & 15 & 50 \\
\hline Sarjana & - & 6 & 20 \\
\hline \multicolumn{4}{|l|}{ e. Paritas: } \\
\hline - $\quad$ Ke 1 & - & 16 & 53,3 \\
\hline - $\quad$ Ke 2 & - & 4 & 13,3 \\
\hline$-\quad$ Ke 3 & - & 5 & 16,7 \\
\hline$-\quad$ Ke 4 & - & 5 & 16,7 \\
\hline f. Apgar skor Baik (skor 7_9) & - & 30 & 100 \\
\hline
\end{tabular}

Hasil analisis uji Kolmogorov-Smirnov diperoleh pada data intersitas nyeri sebelum perlakuan menunjukkan $p=0,074$, sesudah perlakuan $p=0,139$. Kadar $\beta$-Endorphin sebelum perlakuan $p$-value=0,596 dan esudah perlakuan $p=0,217$. Data tersebut menunjukkan keempat data mempunyai distribusi normal. Hasil uji paired t-test perbandingan sebelum dan sesudah terapi menjelaskan ada perbedaan yang sangat bermakna $(p<0,001)$ rerata intersitas nyeri antara pengamatan sebelum perlakuan $(6,80 \pm 1,52)$ dan pengamatan sesudah perlakuan $(3,37 \pm 1,79)$. Hasil ini menunjukkan bahwa pemberian perlakuan terapi murotal Al-Qur'an selama 25 menit menggunakan speaker box music dan earphone mampu menurunkan intersitas nyeri pada ibu bersalin kala I fase aktif.

Hasil juga menunjukkan rerata kadar B-Endorphin pada pengamatan sebelum perlakuan $(1053,6 \pm 606,32 \mathrm{ng} / \mathrm{L})$ lebih rendah secara signifikan $(p=0,000)$ dari pada rerata kadar B-Endorphin sesudah perlakuan $(1813,5 \pm 546,78 \mathrm{ng} / \mathrm{L})$. Hasil ini membuktikan bahwa perlakuan pemberian terapi Murotal Al-Qur'an selama 25 menit menggunakan speaker box music dan earphone pada ibu bersalin kala I fase aktif mampu meningkatkan kadar 6-Endorphin.

\section{DISKUSI}

Penelitian ini menunjukkan pemberian murotal Al-Qur'an terbukti efektif meningkatkan kadar B-Endorphin pada ibu bersalin kala I fase aktif. Bacaan Al-Qur,an yang dilantunkan dengan tempo lambat, lembut penuh penghayatan dapat menimbulkan suatu respon relaksasi. Faktor lain adalah keyakinan bahwa Al-Qur'an kitab suci yang mengandung firman Allah dan merupakan pedoman hidup bagi manusia. Dengan mendengarkan murotal AlQur'an membawa subjek lebih dekat dengan Tuhannya serta menuntun subjek untuk mengingat dan menyerahkan segala permasalahan yang dimiliki kepada Tuhan. Hal ini akan menambah keadaan relaks, sehingga dengan mendengar bacaan Al-Qur'an dapat juga disebut relaksasi religius (12). Murotal Al-Qur'an yang diperdengarkan dengan menggunakan speaker box music dan earphone mengeluarkan suara atau bunyi yang mengalami vibrasi sehingga menghasilkan gelombang suara yang dapat di dengar oleh telinga, kemudian diteruskan ke N.VIII dan di ubah menjadi impuls listrik selanjutnya diteruskan ke korteks serebri yang berhubungan dengan perasaan untuk di persepsikan. Jika bunyi atau suara di persepsikan dengan baik akan menyebabkan ketenangan. Hal ini menyebabkan hypothalamus dan hypofise anterior mengeluarkan opiate endogenous yaitu b-Endorphin melalui jalur decenden masuk melalui spinal cord yang diaktifkan oleh receptor $\mu$ dan $\sigma$ dan terjadi modulasi di cornu dorsalis. Selanjutnya terjadi interaksi antara stresor atau stimuli nyeri dengan opiate endogenous yaitu B-Endophin sehingga mengeliminasi stimuli tersebut yaitu histamin, bradikinin, serotonin, substansi peptide $(11,13,14)$.

Penelitian menunjukkan terapi Murotal Al-Qur'an Surah Ar-rahman menurunkan intensitas nyeri persalinan. Penelitian oleh Faradisi (14) membandingkan terapi Murotal dan terapi Musik Klasik terhadap penurunan tingkat kecemasan pada pasien pra operasi dengan menggunakan MP3 yang berisikan musik Klasik dan Murotal. Hasil uji beda menunjukkan pemberian murotal lebih efektif menurunkan kecemasan pasien dalam menghadapi pra operasi dibanding dengan terapi musik 
klasik. Penelitian yang pernah dilakukan oleh Widhowati dengan memberikan terapi audio dengan murotal AQur'an Surat Ar-rahman kepada pasien di rumah sakit jiwa untuk menurunkan prilaku kekerasan menunjukkan adanya perbedaan yang signifikan terhadap kelompok kontrol dan perlakuan. Hasil pada kelompok perlakuan menunjukkan terapi murotal Al-Qur'an lebih efektif menurunkan kekerasan dibanding dengan terapi musik klasik (15). Penelitian yang dilakukan oleh Siswantinah dengan memberikan terapi murotal pada pasien gagal ginjal kronik yang dilakukan tindakan hemodialisa menunjukkan bahwa pasien yang diberi terapi murotal mengalami penurunan tingkat kecemasan (16).

Lantunan Al-Qur,an secara fisik mengandung suara manusia yang merupakan instrumen penyembuhan yang menakjubkan. Suara dapat menurunkan hormon stres,

\section{DAFTAR PUSTAKA}

1. Larasaty IP and Wibowo A. Pengaruh Keikutsertaan Senam Hamil terhadap Kecemasan Primigravida Trimester Ketiga dalam Menghadapi Persalinan. Jurnal Biometrika dan Kependudukan. 2012; 1(1): 2632.

2. Hutahuju P. Pemberian Valetamat Bromida Dibandingkan Hioscine Butil Bromida untuk Mengurangi Nyeri Persalinan. [Tesis]. Universitas Sumatra Utara, Medan. 2003.

3. Aprilia Y. Hipnostetri: Rileks Nyaman dan Aman Saat Hamil dan Melahirkan. Jakarta: Gagas Media; Jakarta; 2010.

4. Ratnaningsih MD. Perbedaan Tingkat Nyeri pada Ibu Bersalin Primipara Kala I Fase Aktif sebelum dan Setelah Diberikan Kompres Panas Kering di Rumah Bersalin Siti Khodijah. [Skripsi]. Universitas Muhammadiyah Semarang, Semarang. 2010.

5. Kovalitskaya YA and Navolostkaya EV. Nonopioid Effect of B-Endorphin. Biochemistry (Moscow). 2011; 76(4): 379-393.

6. Sherwood L. Human physiology: From Cells to System. 8th Edition. Canadia: International Thomson; 2011.

7. Nandhra TS and Carson RJ. 6-Endorphin Inhibits the Production of Inter 8 by Human Chorio Decidual Cells in Culture. Molecular Human Reproduction. 2000; 6(6): 555-560.

8. Ghofar A and Ningsih L. The Influence of Therapy and Music Therapy: Listening Al-Qur'an Juz Amma to Anxiety Responden at Todler. Prosiding Seminar Competitive Advantage Unipdu. Jombang.

9. Ratnawati S, Sunarsih, dan Dharmaningrum WK. Hubungan antara Paritas dan Nyeri Persalinan pada Kala I Fase Aktif di Bidan Praktek Swasta Eny Juaniarty. Jurnal Penelitian Kesehatan Suara Forikes. 2011; 2(3): 152-160.

10. Permanasari I. Pengaruh Mendengarkan Ayat Suci Al- mengaktifkan hormon endorphin alami sehingga meningkatkan perasaan rileks dan mengalihkan perhatian dari rasa takut, cemas dan tegang, memperbaiki sistem kimia tubuh (17). Tubuh memiliki metode mengontrol rasa nyeri persalinan dalam B-Endorphin yang merupakan opiate endogenous berfungsi sebagai neurotransmitter analgesik, zat ini dikeluarkan dari jalur analgesik decenden dan berikatan dengan receptor opiate di ujung prasinaps aferen pengikatan ini menekan substance peptide sehingga terjadi penghambatan terhadap penyaluran sinyal nyeri (18). Penelitian ini membuktikan pemberian terapi murotal Al-Qur'an surat Ar-rahman selama 25 menit dapat meningkatkan kadar B-Endorphin dan menurunkan intensitas nyeri pada ibu bersalin kala I fase aktif tanpa membedakan apakah ibu termasuk primipara atau multipara.

Qur'an terhadap Tingkat Nyeri Persalinan Kala I Fase Aktif pada Primipara di Puskesmas Mergangsang Yogyakarta. [Skripsi]. Universitas Muhammadiyah Yogyakarta, Yogyakarta. 2010.

11. Tamaroh E dan Puspitosari WA. Pengaruh Mendengarkan Bacaan Al-Qur'an terhadap Skor Depresi Lansia di Panti Sosial Trisna Werdha Budi Luhur Kasongan Bantul Yogyakarta. [Skripsi]. Universitas Muhammadiyah Yogyakarta, Yogyakarta. 2008.

12. Faradisi F. Efektivitas Terapi Murotal Al-Qur'an dan Terapi Musik Klasik terhadap Penurunan Tingkat Kecemasan Pasien Pra Operasi Di Pekalongan. Jurnal Ilmiah Kesehatan. 2012; 5(2): 1-11.

13. Dunn K. Music and the Reduction of Post Operative Pain. Nursing Standard. 2004; 18(36): 33-39.

14. Prasetyo EP. Peran Musik Sebagai Fasilitas dalam Praktek Dokter Gigi untuk Mengurangi Kecemasan Pasien. Dental Journal (Majalah Kedokteran Gigi). 2005; 38(1): 41-44.

15. Widhowati SS. Efektifitas Terapi Audio dengan Murotal Surah Arrahman untuk Menurunkan Prilaku Kekerasan di RSJD Amino Gondo Hutomo. [Tesis]. Universitas Diponegoro, Semarang. 2010.

16. Siswantinah. Pengaruh Terapi Murotal terhadap Kecemasan Pasien Gagal Ginjal Kronik yang Dilakukan Tindakan Hemodialisa di RSUD Kraton Kabupaten Pekalongan. [Tesis]. Universitas Muhammadiyah Semarang, Semarang. 2011.

17. Nastiti RKR, Rejeki S, dan Nurullita U. Pengaruh Efektivitas Teknik Back Edan Teknik Counter Presure terhadap Tingkat Nyeri Pinggang Kala I Fase Aktif Persalinan Di RSUD Ambarawa. [Skripsi]. Universitas Muhammadiyah Semarang, Semarang. 2012.

18. Sprouseblum-Blum AS, Smith G, Sugai D, and Parsa FD. Understanding Endorphins and their Importance in Pain Management. Hawai'i Medical Journal. 2010; 69(3): 70-71. 